\title{
Article
}

Mycosphere

Doi 10.5943/mycosphere/7/3/5

Copyright () Guizhou Academy of Agricultural Sciences

\section{Mycophagy by small mammals: new and interesting observations from Brazil}

\section{Trierveiler-Pereira $\mathrm{L}^{1}$, Silva $\mathrm{HCS}^{2}$, Funez $\mathrm{LA}^{3}$ and Baltazar $\mathrm{JM}^{4}$}

\author{
${ }^{1}$ Universidade Estadual de Maringá (UEM), Maringá, Paraná, Brazil. E-mail: Lt_pereira@yahoo.com.br \\ ${ }^{2}$ Universidade Federal do Acre (UFAC), Rio Branco, Acre, Brazil. E-mail:hebersonbiologo@gmail.com \\ ${ }^{3}$ Universidade Federal de Santa Catarina (UFSC), Florianópolis, Santa Catarina, Brazil. E-mail: lfunezz@gmail.com \\ ${ }^{4}$ Universidade Federal de São Carlos (UFSCar), Campus Lagoa do Sino, Buri, São Paulo, Brazil. E-mail: \\ baltazarjmb@gmail.com
}

Trierveiler-Pereira L, Silva HCS, Funez LA, Baltazar JM. 2016 - Mycophagy by small mammals: new and interesting observations from Brazil. Mycosphere 7(3), 297-304, Doi 10.5943/mycosphere/7/3/5

\begin{abstract}
Events of mycophagy by Brazilian native mammals are not often reported in literature, and the identity of the consumed fungal species is not always available. Therefore, the aim of this article is to report two field observations of mycophagy in Southern and Northern Brazil, involving the black-capped squirrel monkey (Saimiri boliviensis) and the Azara's agouti (Dasyprocta azarae). The primates were observed eating ascomata of Ascopolyporus sp. (Cordycipitaceae, Hypocreales), while the rodents were consuming immature stages ('eggs') of Itajahya galericulata (Phallaceae, Phallales).
\end{abstract}

Key words - feeding behavior - fungivory - mushroom - mutualism - primates - rodents

\section{Introduction}

The term mycophagous is applied to animals that have the consumption of fungi as part of their diets (Merritt 2010). Many species are known to have this habit, including birds (Simpson 2000, Trappe et al. 2009, Tanney \& Hutchison 2010), invertebrates (Moore 1996, Boddy \& Jones 2008), mammals (Fogel \& Trappe 1978, Claridge 2002, Claridge \& Trappe 2005), and turtles (Vasco-Palacios et al. 2008).

The fungivorous habit of small mammals, notably being more common among mammals weighing less than three kilos, is well documented in literature and the dependence on fungi as food resource may vary greatly according to the species (Claridge 2002). Mammal mycophagy has been reported for centuries (Trappe et al. 2009) and most records are from North America (Fogel \& Trappe 1978, Claridge \& Trappe 2005, Castillo-Guevara et al. 2012) and Australia (Claridge \& May 1994, Claridge 2002), but there are also records from Europe (Schickmann et al. 2012, Kataržytė \& Kutorga 2010) and Japan (Sawada et al. 2013, Sawada 2014).

In South America, mycophagy by mammals has been reported for rodents and the ninebanded armadillo (Dasypus novemcinctus novemcinctus) in Argentina (Perez Calvo et al. 1989, Nouhra et al. 2005); as well as deer (Mazama spp.) and the Amazon dwarf squirrel (Microsciurus flaviventer) in Colombia (Vasco-Palacios et al. 2008). Moreover, the mycophagous habit of small monkeys (marmosets and tamarins) has been continuously investigated in Bolivia (Porter 2001, Porter et al. 2007, Porter \& Garber 2010, Hanson et al. 2003, 2006). 
In Brazil, the consumption of fungi by native mammals has been reported a few times. Nevertheless, the name of the fungal species is not always available. For example, Peres (1993) reported that Amazonian tamarins of the genus Saguinus had "bracket fungi" as part of their diets, and Correa et al. (2000) stated that Callithrix aurita (buffy-tufted-ear marmoset) could spend up to $19 \%$ of their feeding time consuming fungi, but fungal species names were not mentioned.

Many studies regarding mammals and mycophagy involve sequestrate, hypogeous species, which lack mechanisms of spore discharge and are dependent upon external vectors to disperse their spores. Therefore, it has been shown that mycophagy is not only important for these mammals as a food source, but it is also important for forest ecosystems, since the process distributes mycorrhizal fungi to new tree roots and indirectly influence vegetation succession (Trappe et al. 2009, Schickmann et al. 2012). Epigeous basidiomata (e.g., mushrooms, stinkhorns, bracket fungi) are very diverse and abundant in forest environments; however, they have received much less attention than those hypogeous fungi consumed by mammals (Castillo-Guevara et al. 2012).

Different methodologies have been used to investigate the mycophagous diet of small mammals, including analysis of stomach contents and fecal pellets, feeding experiments and controlled feeding trials, and more rarely, fortuitous field observations (Fogel \& Trappe 1978, Colgan et al. 1997). Here we report two different events of fungivorous behavior involving primates and rodents observed in the field in order to improve the knowledge about mycophagy by Brazilian mammals.

\section{Materials \& Methods}

\section{Observation areas}

Present reports are based on direct observation of fungivorous behavior. Events were observed in Northern and Southern Brazil (Fig. 1).

The first observation was made in the Catuaba Experimental Farm $\left(10^{\circ} 4^{\prime} 36^{\prime \prime} \mathrm{S}, 67^{\circ} 37^{\prime} 0^{\prime \prime} \mathrm{W}\right)$, which belongs to the Federal University of Acre (UFAC). This farm is located in the municipality of Senador Guimard, (State of Acre) and has an area of ca. 850 ha, most of which of original Amazon Forest or secondary forest under natural recovery. Most common trees and palm species found in the area are Allophylus floribundus Radlk., Bertholletia excelsa O. Berg, Carapa guianensis Aubl., Couratari sp., Euterpe precatoria Mart., Quararibea guianensis Aubl., Rinoreocarpus ulei Aubl. and Tetragastris altıssima (Aubl.) Swart. Also, there are several spots of open forest dominated by the native bamboo Guadua weberbaueri Pilg. (Silveira 2005, Duarte 2006, Costa et al. 2012).

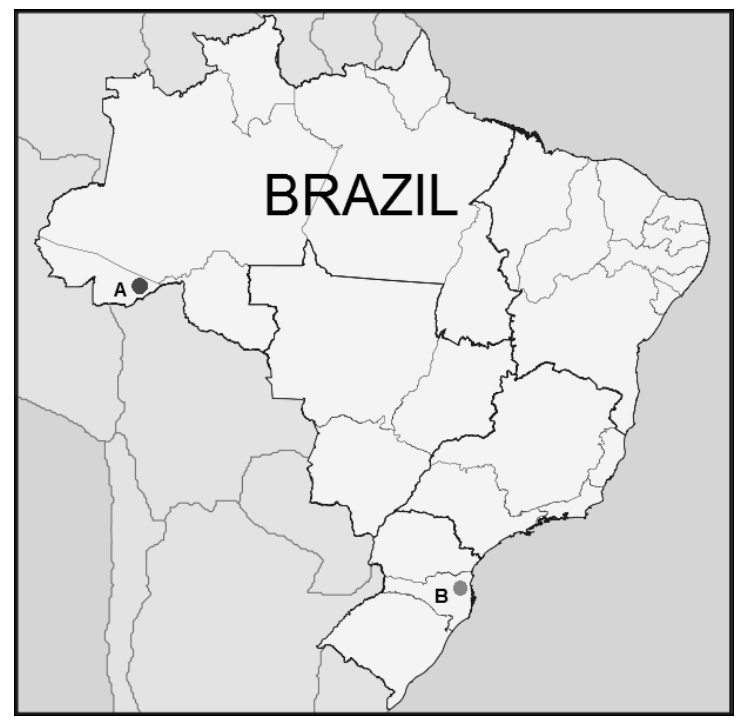

Fig. 1 - Field observation sites. A. City of Senador Guimard, State of Acre. B. City of Blumenau, State of Santa Catarina. Map modified from https://www.wikipedia.org/ 
The second observation was made in the city of Blumenau (26 $\left.54^{\prime} 32^{\prime \prime S}, 49^{\circ} 4^{\prime} 20^{\prime \prime} \mathrm{W}\right)$, State of Santa Catarina, which is situated in the Atlantic Forest Biome. The place where the observation occurred is under natural recovery and is dominated by the trees and palm species Alchornea glandulosa Poepp., Campomanesia reitziana D. Legrand, Eugenia brasiliensis Lam., Euterpe edulis Lam. and Psychotria velloziana Lam.

\section{Taxonomic identification}

Mammal species were identified by zoologists from the Federal University of Acre and Federal University of Santa Catarina. All data collection was non-invasive and animals were not captured for this study. Fungal species were photographed and identified following traditional methods of taxonomy of macrofungi based on field experience and taxonomic literature (Möller 1895, 1901, Miller \& Miller 1988, Trierveiler-Pereira 2015). Immature stages of Phallales were kept in a moist chamber until basidiomata were completely expanded.

\section{Results}

\section{Primates and ascomycetes}

During a study involving the feeding habits of Saimiri boliviensis (common names: blackcapped squirrel monkey and Bolivian squirrel monkey) (Fig. 2A) accomplished 2012 in the Brazilian Amazon Forest, a group of about eight individuals was observed at the end of the day foraging on native bamboo (Guadua weberbaueri) (Fig. 2B). The monkeys were removing from the substrata small ascomata of Ascopolyporus spp. (Fig. 2C-D), an ascomycete species which is parasitic on scale insects that, in turn, are parasitic on the bamboo.

The fungal species are morphological similar to A. polyporoides Möller and A. polychrous Möller, but since the ascomata were not examined microscopically, we cannot assert their identities. This feeding behavior was observed during the dry season in the Amazon (MaySeptember), when there is scarcity of fruits. As a consequence, these small monkeys would search for fungi as an alternative food source.

\section{Rodents and basidiomycetes}

For at least five years it has been observed in the same area in Blumenau that some individuals of Dasyprocta azarae (common name: Azara's agouti) (Fig. 3A) have a voracious appetite for small, light-colored, gelatinous spheres that appear on the ground. The agoutis arrive in the early morning and/or at the end of the day and dig through the litter fall, searching for the spheres. The spheres, which are immature fungal fruiting bodies, would always grow at the same location during spring and summer (September-March), without completing their development since the agoutis would decimate them before they could finish the expanding process. The agoutis show a preference for the larger spheres, eating the inner contents and leaving the external, gelatinous layer.

After keeping some of these immature fungi in a moist chamber (April/2012), it was discovered that they developed into the basidiomata of Itajahya galericulata Möller (Fig. 3B).

\section{Discussion}

Saimiri monkeys are mainly frugivores, but they can also complement their diet with insects (Baldwin \& Baldwin 1988). Here we report for the first time that S. boliviensis also have fungi as an alternative food source during the dry-season in the Brazilian Amazon, when fruits are not abundant.

Nearly 60 species of primates are known to have mycophagous behaviour (Sawada 2014), however, most of them spend less than $5 \%$ of their feeding time consuming fungi (Hanson et al. 2003). Some species, such as Callithrix aurita, could spend up to $19 \%$ of their feeding time consuming fungi (Correa et al. 2000). Hilário \& Ferrari (2010) observed that the diet of the Brazilian buffy-headed marmoset (Callithrix flaviceps) is highly dependent on fungal resources, 
and marmosets would consume two different Clavicipitaceae species, identified by the authors as Mycocitrus spp.

Goeldi's monkey (Callimico goeldii) also has a diet largely dependent on fungal ascomata and basidiomata (feeding time on fungi may reach 63\%) of a few species: Auricularia auricula (L.) Underw., A. delicata (Mont. ex Fr.) Henn., Ascopolyporus polyporoides and A. polychrous (Hanson et al. 2003, 2006, Porter 2001). On the other hand, it has been reported that Japanese macaques (Macaca fuscata yakui) consume up to 67 different fungal species (Sawada et al. 2013).

Ascopolyporus spp. and other members of Clavicipitaceae seem to be a common fungal food source for several species of small monkeys of the New World (e.g., S. boliviensis, C. flaviceps, $C$. goeldii). Further studies are necessary to discover if $S$. boliviensis also consumes other species or if its fungal ingestions are restricted to Ascopolyporus spp.
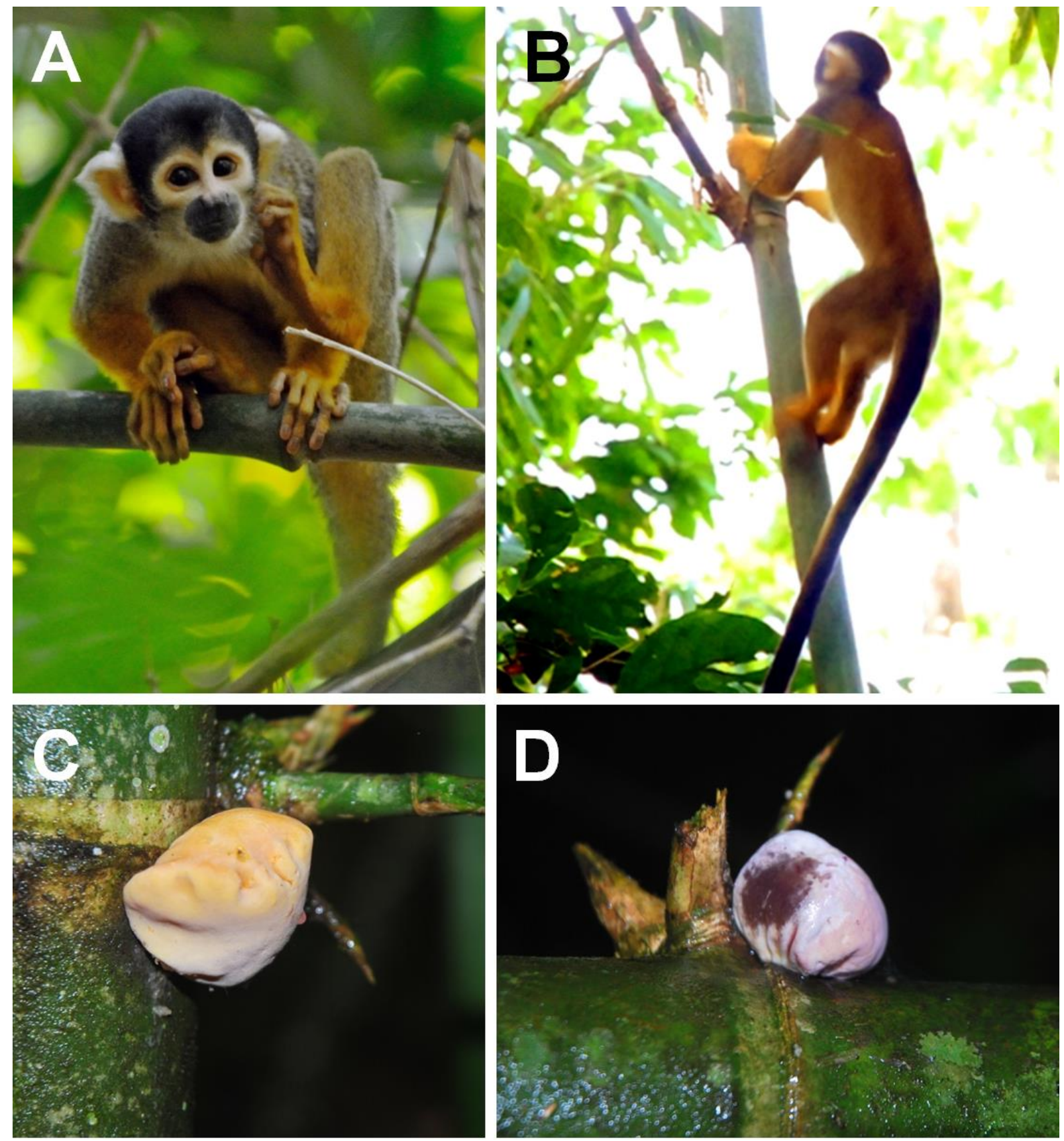

Fig. 2A. - Saimiri boliviensis on native bamboo (Guadua weberbaueri). B. Saimiri boliviensis foraging on bamboo. C-D. Ascomata of Ascopolyporus. Photograph A by Tomaz Nascimento de Melo, B-D by Heberson Cristiano S. Silva. 
Agoutis are forest-dwelling animals that in Brazil could appear in urban areas and become comfortable with the human presence. They are known for being frugivores, feeding on fruits, leaves, seeds, nuts, and roots (Catzeflis et al. 2008, Kaiser et al. 2011). In Blumenau, it was observed that the agoutis would return every year to the same place, expecting to find the phalloid's eggs. It would be interesting to investigate if I. galericulata is associated with Jacaranda puberula Cham., a tree that is present in this area, since in Africa it was observed occurring in association with the tree Jacaranda mimosifolia D. Don (Marincowitz et al. 2015).

In Mexico, Estrada Croker \& Naranjo Piñera (1998) documented events of mycophagy involving Dasyprocta mexicana (Mexican agouti), which can consume up to 10 different fungal species of Agaricales, Aphyllophorales and Auriculariales. According to Fogel \& Trappe (1978), several epigeous fungal species are known to be consumed by rodents, including members of the genera Amanita, Clitocybe, Mycena, Paxillus, Polyporus, and Sparassis, although most records are from rodents eating hypogeous, truffle-like fungi (Maser et al. 1978, Claridge 2002, Vernes \& McGrath 2009, Schickmann et al. 2012). This appears to be the first known report of a rodent consuming a phalloid species.
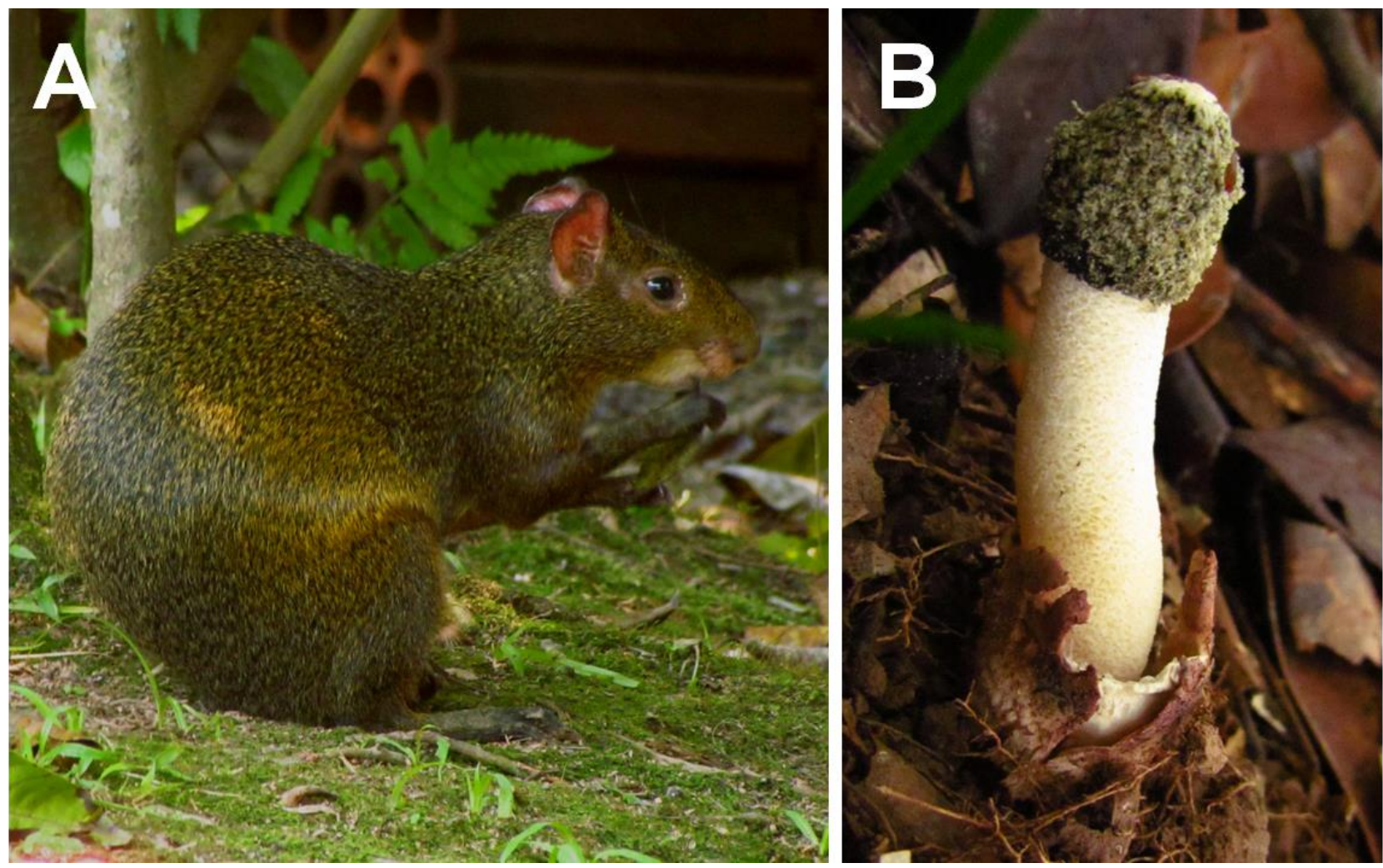

Fig. 3A. - Azara's agouti foraging. B. Expanded basidiome of Itajahya galericulata Möller. Photographs by Luís A. Funez.

Major reviews on mycophagy by mammals (Fogel \& Trappe 1978, Claridge \& May 1994) do not report the consumption of phalloid fungi, but Sawada et al. (2013) observed that Japanese macaques consume Phallus impudicus L.. In Australia, it was observed that the red-necked wallaby (Macropus rufogriseus) can consume basidiomata of Ileodictyon gracile Berk. (Fig. 4), although it hasn't yet been documented in literature, e.g., by Claridge \& May (1994).

Basidiospores of Phallales are well known to be dispersed by insects and other arthropods (Hosaka \& Uno 2012). When expanded, basidiomata usually emit a strong, fetid odor that attracts flies, beetles and ants (Nouhra \& Dominguéz de Toledo 1994). Sometimes the attack of insects on these fungi is so intense that they can destroy the basidiomata within a few hours. Possibly because of the attack of insects, it's rare to witness mammals eating phalloid fungi. 
Moreover, many records of mycophagy are based on fecal composition, instead of direct observation, and spores of Phallales are not documented from animal feces (Hosaka et al. 2006). Perhaps this is because the spores of truffle-like fungi consumed by mammals are usually large, pigmented, ornamented and therefore they are easier to identify, unlike phalloid basidiospores, which are mainly small, hyaline and smooth (Trierveiler-Pereira et al. 2014).
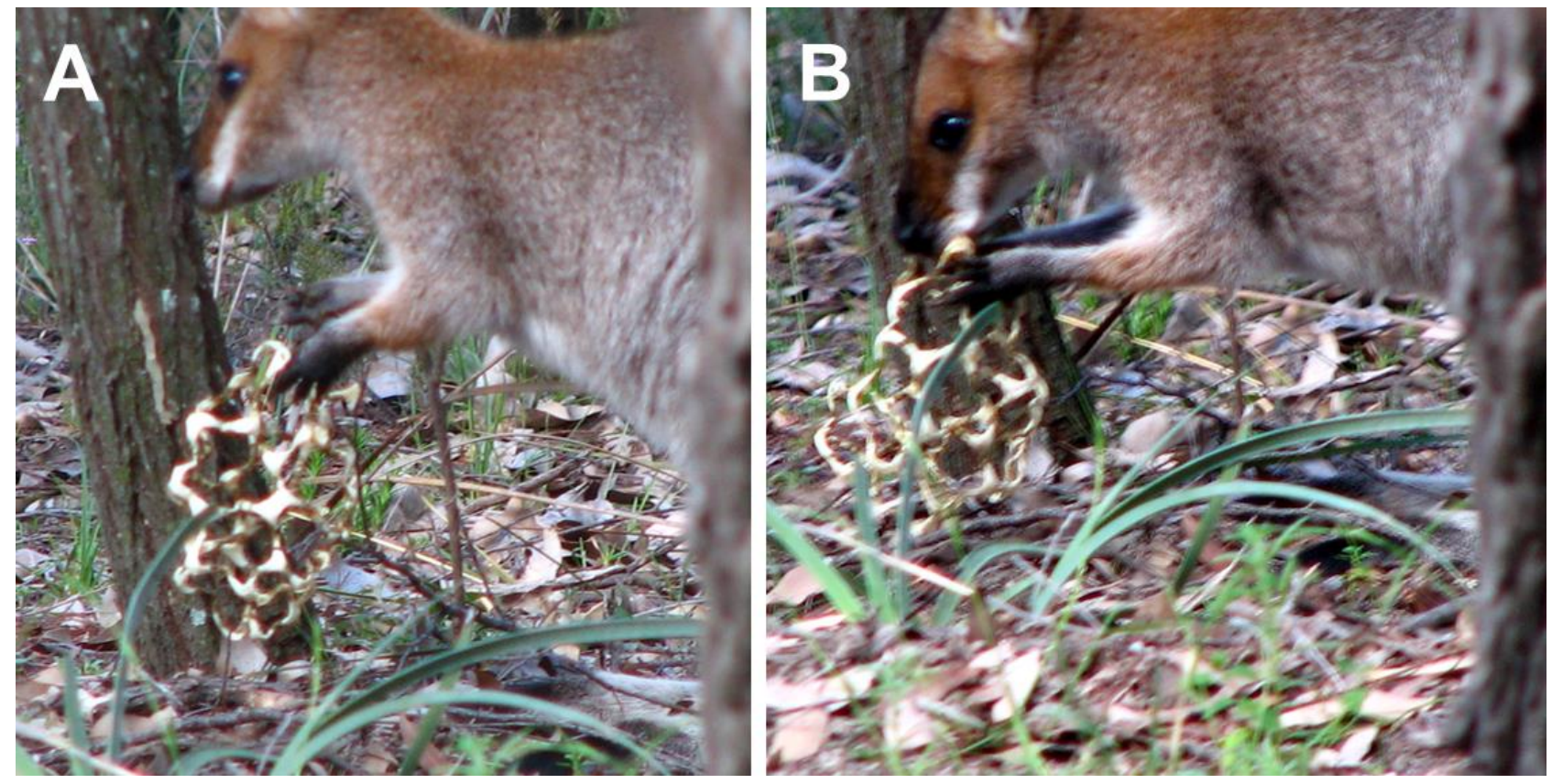

Fig. 4 - Red-necked wallaby examining and eating a basidiome of Ileodictyon gracile Berk., in Girraween National Park, Queensland, Australia. Photographs by Melanie Cook.

Mycophagy can be categorized according to the dependence on ascomata and basidiomata for nourishment: obligate, preferential, casual or opportunistic and accidental (Claridge \& Trappe 2005). In our study, it has been observed that both primates and rodents have ingested fungi as opportunists and most likely their diets do not depend on ascomata and basidiomata.

Future studies involving zoologists, ecologists, and mycologists, such as detailed feeding and foraging data, are desired to better understand the mycophagous behaviours reported here and to estimate how significant the fungal species are for the diet of these Brazilian mammals.

\section{Acknowledgements}

We would like to thank Tomaz Nascimento de Melo and Melanie Cook for photographs, and Hugo B. Mozerle for his inputs on agoutis' species. Vanessa Ryan is acknowledged for the wallaby species identification and corrections on the manuscript. HCS Silva acknowledges Dr. Armando Muniz Calouro and CNPq for his PIBIC scholarship.

\section{References}

Baldwin JD, Baldwin JI. 1988 - The squirrel monkeys, genus Saimiri. In: Mittermeier RA, Rylands AB, Coimbra-Filho AF, Fonseca GAB (eds.) Ecology and behavior of Neotropical primates. World Wildlife Fund, Washington DC, pp. 277-330.

Boddy L, Jones TH. 2008 - Interaction between Basidiomycota and invertebrates. In: Boddy L, Frankland JC, Van West P (eds.) Ecology of saprotrofic Basidiomycetes. Academic Press, London, pp. 155-180.

Castillo-Guevara C, Lara C, Pérez G. 2012 - Micofagia por roedores en un bosque templado del centro de México. Revista Mexicana de Biodiversidad 83, 772-777. 
Catzeflis F, Patton J, Percequillo A, Bonvicino C, Weksler M. 2008 - Dasyprocta azarae. The IUCN Red List of Threatened Species 2008, e.T6278A12595062. http://dx.doi.org/10.2305/IUCN.UK.2008.RLTS.T6278A12595062.en. [accessed 16 March 2016].

Claridge AW, May TW. 1994 - Mycophagy among Australian mammals. Australian Journal of Ecology 19, 251-275.

Claridge AW, Trappe JM. 2005 - Sporocarp mycophagy: nutritional, behavioral, evolutionary, and physiological aspects. In: Dighton J, White JF, Oudemans P (eds.) The fungal community. Its organization and role in the ecosystem, 3rd ed. CRC Press, Boca Raton, pp. 599-611.

Claridge AW. 2002 - Ecological role of hypogeous ectomycorrhizal fungi in Australian forests and woodlands. Plant and Soil 244, 291-305.

Colgan W, Carey AB, Trappe JM. 1997 - A reliable method of analyzing dietaries of mycophagous small mammals. Northwestern Naturalist 78, 65-69.

Correa HKM, Coutinho PEG, Ferrari SF. 2000 - Between-year differences in the feeding ecology of highland marmosets (Callithrix aurita and Callithrix aviceps) in southeastern Brazil. Journal of Zoology 252, 421-427.

Costa SG, Morato EF Salimon CI. 2012 - Densidade de bambu e estrutura populacional de duas espécies arbóreas pioneiras em florestas secundárias de diferentes idades em um remanescente florestal, Acre. Scientia Forestalis 40(95), 363-374.

Duarte AF. 2006 - Aspectos da climatologia do Acre, Brasil, com base no intervalo 1971 - 2000. Revista Brasileira de Meteorologia 21(3b), 308-317.

Estrada Croker JC, Naranjo Piñera EJ. 1998 - Ecología del agutí mexicano (Dasyprocta mexicana) en El Zapotal, Chiapas Instituto de Historia Natural del Estado de Chiapas. Departamento de Información para la Conservación. Informe final SNIB-CONABIO proyecto No. G020, México D.F.

Fogel R, Trappe JM. 1978 - Fungus consumption (mycophagy) by small mammals. Northwest Science 52(1), 1-31.

Hanson A, Hall M, Porter L, Lintzenich B. 2006 - Composition and nutritional characteristics of fungi consumed by Callimico goeldii in Pando, Bolivia. International Journal of Primatology 27(1), 323-346.

Hanson AM, Hodge KT, Porter LM. 2003 - Mycophagy among primates. Mycologist 17(1), 6-10.

Hilário RR, Ferrari SF. 2010 - Feeding ecology of a group of buffy-headed marmosets (Callithrix flaviceps): fungi as a preferred resource. American Journal of Primatology 72 (6), 515-521.

Hosaka K, Bates ST, Beever RE, Castellano MA, Colgan W, Domínguez LS, Nouhra ER, Geml J, Giachini AJ, Kenney SR, Simpson NB, Spatafora JW, Trappe JM. 2006 - Molecular phylogenetics of the gomphoid-phalloid fungi with an establishment of the new subclass Phallomycetidae and two new orders. Mycologia 98(6), 949-959.

Hosaka K, Uno K. 2012 - A preliminary survey on larval diversity in mushroom fruit bodies. Bulletin of the National Museum of Natural Science, Series B 38(3), 77-85.

Kaiser SK, Margarido TCC, Fischer ML. 2011 - Avaliação do comportamento de cutias Dasyprocta azarae e Dasyprocta leporina (Rodentia: Dasyproctidae) em cativeiro e semicativeiro em parques urbanos de Curitiba, Paraná, Brasil. Revista de Etologia 10(2), 68-82.

Kataržyte M, Kutorga E. 2010 - Small mammal mycophagy in hemiboreal forest communities of Lithuania. Central European Journal of Biology 6(3), 446-456.

Marincowitz S, Coetzee MPA, Wilken PM, Wingfield BD, Wingfield MJ. 2015 - Phylogenetic placement of Itajahya: An unusual Jacaranda fungal associate. IMA Fungus 6(2), 257-262.

Maser C, Trappe JM, Ure DC. 1978 - Implications of small mammals mycophagy to the management of Western Coniferous Forests. Transactions of the 43rd North American Wildlife and Natural Resources Conference. Wildlife Management Institute, Washington D.C., pp. $78-88$.

Merritt JF. 2010 - The biology of small mammals. The Johns Hopkins University Press, Baltimore. 
Miller OK , Miller HH. 1988 - Gasteromyecetes: morphological and development features with keys to orders, families, and genera. Mad River Press, Eureka, CA.

Möller A. 1895 - Möller A. 1895. Brasilische Pilzblumen. Botanische Mittheilungen aus den Tropen 7, 1-152.

Möller A. 1901 - Phycomyceten und Ascomyceten untersuchungen aus Brasilien. Botanische Mittheilungen aus den Tropen 9, 1-319.

Moore PD. 1996 - Invertebrates and mycophagy. Nature 381, 372-373.

Nouhra ER, Domínguez de Toledo, LS. 1994 - Interaccion entre Phallales (Basidiomycotina) e insectos (Coleopteros y Dipteros). Boletín de la Sociedad Argentina de Botánica 30(1-2), 21-24.

Nouhra ER, Domínguez LS, Becerra AG, Trappe JM. 2005 - Morphological, molecular and ecological aspects of the South American hypogeous fungus Alpova austroalnicola sp. nov. Mycologia 97(3), 598-604.

Peres CA. 1993 - Diet and feeding ecology of saddle-back (Saguinus fuscicollis) and moustached (S. mystax) tamarins in an Amazonian terra firme forest. Journal of Zoology 230, 567-592.

Perez Calvo JG, Maser Z, Maser C. 1989 - Note on fungi in small mammals from the Nothofagus forest in Argentina. Great Basin Naturalist 49, 618-620.

Porter L. 2001 - Dietary differences among sympatric Callitrichinae in Northern Bolivia: Callimico goeldii, Saguinus fuscicollis and S. labiatus. International Journal of Primatology 22(6), 961-992.

Porter LM, Garber PA. 2010 - Mycophagy and its influence on habitat use and ranging patterns in Callimico goeldii. American Journal of Physical Anthropology 142, 468-475.

Porter LM, Sterr SM, Garber PA. 2007 - Habitat use and ranging behavior of Callimico goeldii. International Journal of Primatology 28, 1035-1058.

Sawada A, Sato H, Inoue E, Otani Y, Hanya G. 2013 - Mycophagy among Japanese macaques in Yakushima: fungal species diversity and behavioral patterns. Primates 55(2), 249-257.

Sawada A. 2014 - Mycophagy among Primates - what has been done and what can be done. Primate Research 30, 5-21.

Schickmann S, Urban A, Kräutler K, Nopp-Mayr U, Hackländer K. 2012 - The interrelationship of mycophagous small mammals and ectomycorrhizal fungi in primeval, disturbed and managed Central European mountainous forests. Oecologia 170, 395-409.

Silveira MA. 2005 - Floresta aberta com bambu no sudoeste da Amazônia. Padrões e processos em múltiplas escalas. EDUFAC, Rio Branco.

Simpson JA. 2000 - More on mycophagous birds. Australian Mycologist 19(2), 49-51.

Tanney JB, Hutchinson LJ. 2010 - A brief survey of mycophagy in ruffed grouse, Bonasa umbellus, from Northwestern Ontario. The Canadian Field-Naturalist 125, 72-73.

Trappe JM, Molina R, Luoma DL, Cázares E, Pilz D, Smith JE, Castellano MA, Miller SL, Trappe MJ. 2009 - Diversity, ecology, and conservation of truffle fungi in forests of the Pacific Northwest. Gen. Tech. Rep. PNW-GTR-772. U.S. Department of Agriculture, Forest Service, Pacific Northwest Research Station, Portland.

Trierveiler-Pereira L, Silveira RMB, Hosaka K. 2014 - Multigene phylogeny of the Phallales (Phallomycetidae, Agaricomycetes) focusing on some previously unrepresented genera. Mycologia 106(5), 904-911.

Trierveiler-Pereira L. 2015 - Phalloid fungi (Phallales) of Brazil. Guide \# 716. Rapid Colour Guides, Field Museum. http://fieldguides.fieldmuseum.org/guides/guide/716 [accessed 02 February 2016].

Vasco-Palacios AM, Suaza SC, Castaño-Betancur M, Franco-Molano AE. 2008 - Conocimiento etnoecólogico de los hongos entre los indígenas Uitoto, Muinane y Andoke de la Amazonía Colombiana. Acta amazônica 38(1), 17-30.

Vernes K, McGrath K. 2009 - Are introduced black rats (Rattus rattus) a functional replacement for mycophagous native rodents in fragmented forests? Fungal Ecology 2, 145-148. 